\title{
Challenges and strategies in the education of primary school children related to microbiological food safety - a review
}

\section{Scientific review article}

Received: 26. 11. 2019

Accepted: 20. 12. 2019

Published: 31. 12. 2019
${ }^{1}$ University of Ljubljana, Faculty of Health Sciences, Zdravstvena pot 5, SI-1000 Ljubljana

* Corresponding author

Prof. Peter Raspor

University of Ljubljana

Faculty of Health Sciences

Zdravstvena pot 5, 1000 Ljubljana

E-mail: peter.raspor@guest.arnes.si

(c) 2019 Andrej Ovca, Mojca Jevšnik, Peter Raspor. This is an open access article licensed under the Creative Commons Attribution-NonCommercialNoDerivsLicense (http://creativecommons. org/licenses/by-nc-nd/3.0/).

\author{
Andrej OVCA ${ }^{1}$, Mojca JEVŠNIK ${ }^{1}$, Peter RASPOR ${ }^{1 *}$
}

\section{ABSTRACT}

Teaching microbiological food safety and food safety in general at the primary school level is crucial, because behaviour is more easily influenced at that stage. The purpose of this review was to identify challenges in the education of primary school children related to microbiological food safety and to review the type of activities published and evaluated in the scientific literature targeting primary school children. The most frequently applied approach in the reviewed studies is target population-tailored workshops. The knowledge, attitude, and practice (KAP) model is most widely used for evaluation purposes, based mostly on the self-report and recall levels. Studies that compared theoretical and practical educational approaches unanimously demonstrated that theoretical awareness is not effective for changing and maintaining appropriate behaviour, whereas experiences had a significant impact. The review highlighted the differences and deficiencies in home economic teachers regarding formal education. The development of proper teaching methodologies and educators seems to be the key to the achievement of aware, confident, and skilled students (on the consumer level) during primary education.

Key words: food safety; education; schoolers; primary school

\section{POVZETEK}

Poučevanje temeljnih principov zagotavljanja mikrobiološke varnosti živil na ravni osnovne šole je lahko ključnega pomena, saj na tej stopnji razvoja lažje vplivamo na zavedanje in ravnanje posameznika. Namen pregleda znanstvene literature na tem področju je ugotoviti izzive, pristope in metode evalvacije pri poučevanju tovrstne tematike na ravni osnovnošolskih otrok. Najpogosteje uporabljen pristop $v$ pregledanih študijah so usmerjene teoretične in/ali praktične delavnice, prilagojene ciljni publiki. Kot orodje za evalvacijo učinka pa se najpogosteje uporabljajo različne oblike t.i. samo poročanja udeležencev glede spremembe znanja, odnosa in ravnanja. Študije zajete $v$ pregled dokazujejo, da imajo praktične izkušnje, ki si jih udeleženci pridobijo tekom udeležbe na delavnici pomemben pozitiven vpliv na spremembo ravnanja $v$ povezavi z zagotavljanjem mikrobiološke varnosti živil. Razkrijejo tudi razlike in 
Consumer behaviours, such as the ingestion of raw/undercooked foods, and poor hygiene practices are significant contributors to outbreaks of food-borne diseases. omejitve učiteljev gospodinjstva na področju njihove formalne izobrazbe. Razvoj ustreznih učnih metod in usposabljanje učiteljev za poučevanje mikrobiološke varnosti živil je eden ključnih korakov za doseganje osveščenih in usposobljenih bodočih potrošnikov že $v$ času osnovnošolskega izobraževanja.

Ključne besede: varnost živil; izobraževanje; učenci; osnovna šola

\section{INTRODUCTION}

Foodstuffs can become a risk for consumers' health if they are not handled and treated along the food supply chain in accordance with food hygiene principles. The food supply chain does not exclude consumers, but the question is whether consumers are sufficiently informed to assure food safety at the end of the food supply chain $[1,2]$. Redmond and Griffith [3] demonstrated that multiple food safety responsibilities are held by consumers, because consumers not only purchase and receive products but also process and provide foods for themselves and others. They also emphasised that the implementation of proper food-handling practices can prevent cases of food-borne disease, and the way in which consumers handle food in the kitchen affects the risk of pathogen multiplication, cross-contamination to other products, and the destruction of pathogens via thorough cooking procedures [3].

Epidemiologic surveillance summaries of food-borne diseases clearly indicate that consumer behaviours, such as the ingestion of raw/ undercooked foods, and poor hygiene practices are significant contributors to outbreaks of food-borne diseases [4]. Unusan [5] reported that people of all ages seem to think they know how to handle food safely, but their self-reported food-handling behaviours do not support this confidence. Wilcock et al. [6] demonstrated that, overall, consumer attitudes towards food safety, in general, differ according to demographic and socio-economic factors, such as gender, age, educational level, and economic status. Consumers need to know which behaviours are most likely to result in illness in order to make decisions about food handling and consumption behaviours [7], and then need to be motivated to act on that knowledge as a precondition for behavioural change [8].

One important perspective is to educate the public about safe food handling and the preparation of foods through different kinds of educational models, which emphasise hazardous food handling techniques and the microbiological causes of food-borne disease. Education about basic food safety principles is generally emphasised as an essential factor contributing to the reduction of foodborne illnesses. As childhood usually coincides with the beginning of meal preparation experiences [9, 10,11], it is recognised as a crucial time for developing food safety knowledge and skills $[12,13]$. Once habits are established during this life period, they tend to be long-lasting and difficult to alter at later life stages regardless of the level of knowledge [14, 15]. This is 
significant because children grow up and, as adults, they will continue to practice food-related behaviours at home as caregivers for family members or possibly as employees in the food business sector.

As shown by Janacsek et al. [16] the most effective time for learning new skills is from childhood to early adolescence. This is also true because children are willing to learn and have fewer previous behaviour patterns to unlearn, as already summarized by Pivarnik et al. [17]. Lavelle et al. [18] reported that learning cooking skills as a child or a teenager was positively related to the use of cooking skills, cooking practices, and cooking attitudes in later life. Food safety education can easily be incorporated into existing school curricula in courses, such as home economics or family and consumer science.

The study by Byrd-Bredbenner et al. [19] revealed that most middle schoolers are interested in food safety based on their positive attitude toward being healthy and their interest in cooking. However, as further reported by Ovca et al. [11], a high level of perceived severity and a low level of perceived vulnerability towards food-related risks are observed among this age group. In combination with confidence in their skills, this may diminish their appropriate food safety practices during food preparation, even in situations in which their knowledge is appropriate.

As further reported by others [11, 20], mothers represent the dominant sources of knowledge related to food safety (although with selective impact) and are also highly trusted sources of information. However, parental influence may be reduced in the future by teachers, peers, and celebrity chefs [21]. Nevertheless, the possibility that children educated in an effective way can act as facilitators at home through messages conveyed to family members should also be considered.

Intervention studies demonstrate a variety in teaching methods with information provision, demonstrations, and practical hands-on sessions [19]. The purpose of this review was, therefore, to identify challenges in the education of primary school children related to microbiological food safety and to review the type of activities published and evaluated in the scientific literature targeting primary school children.

\section{METHODS}

A literature review focusing on articles related to the education of primary school children related to microbiological food safety was conducted in June 2018. A search strategy was implemented in the following bibliographic databases: Scopus, Web of Sciences, and PubMed. The search algorithm comprised a targeted combination of food safety-related terms (food safety, foodhygiene), population terms (children, student) andeducational terms (education, primary school, elementary school).

The titles and abstracts of identified publications were screened for relevance to the scope of the review. Interventions in which food safety was the sole focus or part of broader nutrition-related intervention were the only studies of interest. Studies were considered for review if they
The most effective time for learning new skills is from childhood to early adolescence.

Mothers represent the dominant sources of knowledge related to food safety. 
Most children older than eleven are mature enough to participate in surveys if the language is adapted for them. contained a food safety-related education intervention for children aged 6 to 15 years; studies that included children outside this age range were excluded. Titles and abstracts retrieved from database searches were independently screened by two authors to determine suitability for review. Relevant publications were then procured as full articles, confirmed for relevance, and reviewed in detail considering the following criteria (Type of Activity, Contents, Duration, Number of participants included, Age of participants and Evaluation procedures).

\section{RESULTS AND DISCUSSION}

\section{Challenges}

Cognitive development at this stage allows children to proceed from concrete to abstract thought, meaning that they can consider several dimensions at once and relate them in a thoughtful and relatively abstract manner [22]. However, as elaborated by different authors [12, 19], young children have difficulties comprehending i) microorganisms and their pathogenic effects on the human body, ii) why safe food handling is important, and iii) how to practice safe food handling. As further demonstrated by Byrd-Bredbenner et al. [19], children do not always practice safe food handling because of barriers such as hunger and the importance of other priorities despite their broad knowledge base related to safe food handling and information about how to prevent food poisoning. An additional challenge to the researchers are linguistic limitations and uncertainty about children's comprehension of the basic terms [12]. However, most children older than eleven are mature enough to participate in surveys if the language is adapted for them [23].

If children are to be engaged in food safety education, it needs to be fun, related to real life, and provide opportunities to practice what is learned [24]. There is evidence that children find practical work relatively useful and enjoyable in comparison with other teaching activities [25]. Based on the results further reported by ByrdBredbenner et al. [19], children in the target group wanted food safety education to be fun, interesting, interactive, and visually intense, including hands-on learning. They also wanted the educational materials to be reflective to their lifestyles and habits. Considering the opinions of food safety experts surveyed by Byrd-Bredbenner et al. [19], food safety education should be clear, infused into existing educational activities, presented in a way that makes "it something they want to know," and marketed in a way that makes safe food-handling skills an asset.

Although schools are recognized as essential institutions influencing health-related behaviour [26], home economics as a core subject is seen as less critical than subjects where parents and other teachers perceive it as a less important subject that teaches 'lower-level' skills unlike math and science [27]. As further reported by others [28, 29], there are many barriers cited by primary school teachers to the practical model of teaching food microbiology. These include limited budgets, 
poor access to resources, lack of time, lack of equipment and/or unsuitable classrooms, lack of discipline among students, lack of interest, the number of pupils in the class, and the inability to do experimental work with microorganisms. As further demonstrated by Lange et al. [30], home economics teachers' didactic choices are influenced mostly by budget, lesson time, syllabus, and their routines but also their individual experiences, knowledge and risk perception.

The challenge is linking theory and research and then further linking them to program planning andevaluation [19]. Finally, we should be aware that although teaching is essential for pupils' learning, it is no guarantee of learning [31].

\section{Strategies to cope with challenges}

Reviewed interventions are organized in groups considering the basic approach researchers have applied (Table 1). Different types of activities with a wide range regarding the duration and number of participants are reported. However, the KAP (knowledge, attitude and practice) model is the most widely used for evaluation purposes.

\section{Workshops}

The most frequently applied approach in the reviewed studies (Table 1) is the workshop. All authors designed specifically tailored 40-90-minute workshops with the intention of promoting health and influencing the comprehension of preventive measures targeting food-related risks. The authors applied mostly cross-sectional pre-test/post-test surveys [10, 32, 33], with the exception of Traversa et al. [34] who observed participants and their replies to the questions and practical activities proposed during the workshop. For evaluation purposes, only some of them applied control group and monitored short-term and long-term effects among the target population [10, 33].

In the context of food safety, Kim and Lee [32] focused on proper handwashing and the recognition of potentially unsafe foods. Ovca et al. [10] addressed the impact of temperature on microorganisms, the cleaning of kitchen gear, the removal of bacteria with hand washing, and the prevention of cross-contamination. Traversa et al. [34] focused on characteristics and differences among microorganisms in the context of cooking, storage, and cross-contamination. Cross-contamination was also addressed in the case of allergens. Zhou et al. [33] focused on durability (shelf life), food-related incidents, and food product safety. They were also the only one including gamification (games with an educational aspects) in the workshop through a prize contest.
We should be aware that although teaching is essential for pupils' learning, it is no guarantee of learning. 
Table 1. Characteristics of included studies targeting primary school-aged children with food safety-related interventions

\begin{tabular}{|c|c|c|c|c|c|}
\hline Type of Activity & Duration & $\begin{array}{l}\text { Number of } \\
\text { participants }\end{array}$ & $\begin{array}{l}\text { Age of target } \\
\text { population }\end{array}$ & $\begin{array}{l}\text { Dimensions } \\
\text { evaluated }\end{array}$ & Reference \\
\hline \multirow[t]{4}{*}{ Workshop } & 40 minutes & 8370 & $10-11$ & $\begin{array}{l}\text { Awareness } \\
\text { Self- reported practices }\end{array}$ & [32] \\
\hline & 45 minutes & 671 & $10-12$ & $\begin{array}{l}\text { Knowledge } \\
\text { Susceptibility } \\
\text { Self-reported behaviour }\end{array}$ & [10] \\
\hline & 90 minutes & 1708 & $6-11$ & $\begin{array}{l}\text { Knowledge } \\
\text { Awareness } \\
\text { Practice }\end{array}$ & [34] \\
\hline & 40 minutes & 501 & $10-14$ & $\begin{array}{l}\text { Knowledge } \\
\text { Awareness } \\
\text { Practice }\end{array}$ & [33] \\
\hline \multirow[t]{3}{*}{$\begin{array}{l}\text { Role model } \\
\text { (Detectives, Chefs, } \\
\text { Scientists) }\end{array}$} & $\begin{array}{l}6 \text { sessions } \\
\text { (30-60 minutes } \\
\text { each. }\end{array}$ & 561 & $7-9$ & Knowledge & [38] \\
\hline & $\begin{array}{l}3 \text { sessions to } \\
\text { over a year. }\end{array}$ & 86 & 9-11 & $\begin{array}{l}\text { Confidence } \\
\text { Behaviour }\end{array}$ & [35] \\
\hline & 3 days & 1812 & $8-18$ & Knowledge & [36] \\
\hline $\begin{array}{l}\text { Health promotion } \\
\text { campaign }\end{array}$ & $\begin{array}{l}\text { two lessons of } \\
\text { two hours each }\end{array}$ & 249 & $9-11$ & $\begin{array}{l}\text { Knowledge } \\
\text { Understanding } \\
\text { Self-reported behaviour }\end{array}$ & {$[12,29,37]$} \\
\hline $\begin{array}{l}\text { Multimedia,self- } \\
\text { paced online } \\
\text { resource }\end{array}$ & 19 days & 300 & $11-14$ & $\begin{array}{l}\text { Knowledge } \\
\text { Attitude }\end{array}$ & [38] \\
\hline \multirow[t]{2}{*}{$\begin{array}{l}\text { Long-term } \\
\text { programmes }\end{array}$} & 9 months & 856 & $10-12$ & $\begin{array}{l}\text { Knowledge, } \\
\text { Attitude } \\
\text { Practice }\end{array}$ & [39] \\
\hline & $\begin{array}{l}\text { once a week } \\
\text { within } 50-60 \\
\text { minutes duration } \\
\text { ( } 6 \text { months) }\end{array}$ & 112 & $\begin{array}{l}\text { Elementary } \\
\text { school }\end{array}$ & $\begin{array}{l}\text { Knowledge } \\
\text { Attitude } \\
\text { Practice }\end{array}$ & {$[40]$} \\
\hline
\end{tabular}

As reported by Ovca et al. [10], the positive effects of workshops on knowledge and awareness are mostly of a long-term nature, showing that simplification of information and communication was on the level understood by the target group. The improvement after the intervention was much more significant if substantiated with an experiment or practical activity in comparison to the measures addressed only orally during the workshop. Furthermore, Traversa et al. [34] reported that children enthusiastically engaged with the practical experiences during the workshops, while Kim and Lee [32], who did not apply practical activity in which children would be involved, reported minor although significant improvement of self-reported hand-washing.

\section{Role model}

In this group of activities, approaches in which the target group of children was taking part in different scenarios are combined. In all three reported cases, novelty played an essential part of the delivery. Pivarnik et al. [17] developed a programme entitled "Discovering Food Safety - 
Detective Mike Robe's Fantastic Journey" in which students and detective investigated the "mystery of food safety" to prevent a threat to food safety at a local carnival. During the programme, interactive and experiential learning techniques were applied to teach students to identify food-safety problems during food preparation and storage, to show them how to prevent potential hazards, and to recognize possible consequences of foodborne illness. During the delivery of the program, colouring books, worksheets, hands-on science experiments, a puppet show, and games designed to reinforce concepts and to evaluate knowledge gained were applied. The results and evaluations reported support the suitability of the target group. Analysis revealed a significant increase of food-safety knowledge.

The sessions with a chef were part of a national programme in the UK in which professional chefs linked with local primary schools deliver three sessions to a class covering healthy eating, practical food preparation, and a visit to a restaurant when possible [35]. The intervention had an impact on children's cooking confidence and motivated children to want to cook more. In particular, the children enjoyed having a chef delivering the session. However, a large group size and a small number of sessions left some of the children frustrated, because there was little opportunity for them to work independently.

Marklinder and Erikkson [36] introduced school-children to a scientific way of working, putting them into the role of young scientists collecting the data on refrigerator temperatures in private homes. The students were instructed to record the air temperature on three different shelves in the selected refrigerator. At each recording, the best-before date or expiry date of the existing food items was also recorded.

While Swedish teachers reported that the observational investigation increased interest and knowledge of date labelling, food hygiene, refrigerator storage, and food wastage among students [36], some US teachers preferred to have trained individuals in their classroom to execute the programme [38]. The limitation of the approach in which chefs were included is that they were without any formal nutrition or home economics training raising the issues of the correctness and consistency of the message they delivered [35].

\section{Health campaign}

Faccio et al. [12, 37] and Losasso et al. [29] developed and evaluated a health campaign addressing the knowledge of foodborne communicable diseases, and the importance of proper food preparation and storage. They divided participants into theoretical and practical groups based on two different teaching approaches and compared pre-treatment and posttreatment data. They also investigated the potential of drawings in comparison to questionnaires and interviews as an evaluation approach.

Although both practical and theoretical approaches demonstrate improvement among the target populations, the practical one was more tailored to children's cognitive needs. The authors reported that students in the practical group represented microorganisms more in the
While Swedish teachers reported that the observational investigation increased interest and knowledge of date labelling, food hygiene, refrigerator storage, and food wastage among students [36], some US teachers preferred to have trained individuals in their classroom to execute the programme. 
Detailed analysis revealed that the web application was not appropriate for the younger grade levels ( $>7^{\text {th }}$ grade) . context in which microorganisms are found and their actions defining through illustration of the causal linkage between the actions of microorganisms and the subsequent consequences on people. The practical group was more informed about hand-washing after touching raw meat, covering one's mouth when sneezing, and storing food in the correct way. Drawings were demonstrated to be an ecological method adapted to children's competences and abilities effective in preserving and stimulating children's creativity. The authors concluded that children were able to depict in their drawings all the critical elements corresponding to the explanations they had received in the programme [12].

\section{Multimedia}

Lynch et al. [38] developed a web-based, interactive, multimedia program engaging students in learning about food safety through the use of computers and the Internet. The web application consisted of animations, videos, games, and quizzes to convey the various food safety topics. Each lesson was delivered by an animated professor. Interactive games and activities were based on the material from the lessons, and students tested their knowledge by taking short quizzes after completing each module. The evaluation was done through preand post-test assessments.

Teachers and students were excited about using the web-based program. Although the general difference between the pre-test and post-test was statistically significant,it was much smaller than expected by the authors. Detailed analysis revealed that the web application was not appropriate for the younger grade levels ( $>7^{\text {th }}$ grade). The authors emphasise the major advantage of this approach through the possibility of meeting the needs of all students, regardless of learning style.

\section{Long-term programmes}

Two long-term programmes are also reported in the reviewed literature (Table 1). Riyanto et el. [40] used bookcovers consisting of materials on bacteriological and chemical food safety and two 22-minute long videos. They distributed ten kinds of book covers to each student during the first week of intervention. The food safety education was given through book covers every week while videos were given three times within six months (at the beginning, in the third, and the sixth months of the intervention). The videos focused on street food practices (purchasing, reading labels) and food-borne diseases. Shen et al. [39] applied nutrition and food safety textbooks, taking into account local characteristics with several issues specifically emphasized, according to the results of the baseline investigation. During the lectures, gamification was also applied. Broadcasts and bulletins were used for educational purposes.

Both research groups applied a pre-test-post-test control group design. While Riyanto et al. [40] reported assessment done three times (before the first intervention, after the second intervention, and after the third 
intervention, regarding the videos) Shen et al. [38] reported the baseline and final evaluation.

Riyanto et al. [40] reported that the knowledge, attitudes, and practices of street food safety improved significantly after six months when the pre-intervention and post-intervention results were analysed. The highest improvement was detected in the students' knowledge regarding the impact of unsafe street food on health. Shen et al. [39] reported that the programme improved knowledge and behaviour scores but had no effect on attitude.

\section{DISCUSSION}

The analysed studies (Table 1) with different intervention lengths, ranging from one school hour to a regular programme over several months with diverse outcome measurements, makes determining best practices difficult. Despite differences in delivery, each intervention had some effect on participants' knowledge, attitude and/or behaviour. Data collection methods are mostly on the self-report and recall level. However, observations [34, 35] or children's drawings [12] were also applied for evaluation purposes. As Marklinder and Erikkson [36] warned, all kinds of measurements of a self-reported nature must be interpreted with caution.

Studies that compared theoretical and practical educational approaches unanimously demonstrated that theoretical awareness is not effective for changing and maintaining appropriate behaviour, whereas experiences had significant impact [10, 12, 34, 37]. If children can participate in experiments, they see their participation as an amusing game, as further discussed by Faccio et al. [12] However, based on their literature review, Caraher et al. [35] concluded that practical cooking sessions have a greater impact on the cooking confidence of older primary school children. Furthermore, improvement of attitude is frequently evaluated, and improvement is reported [10, 38, 40]. However, as further discussed by Caraher et al. [35], a positive attitude is essential to achieving changes in behaviour, but the attitude itself does not necessarily translate into behaviour changes, whereas the latter is harder to achieve than the former. Self-efficacy, expressed as the confidence to perform food preparation activities properly, was examined only in one study [10], in which, despite their recognition that mistakes during food preparation, potentially leading to health problems, can be made, participants do not see themselves as a possible cause, also after intervention. Byrd-Bredbenner et al. [19] suggested that food safety education should equip primary schoolers with strategies to overcome barriers that are preventing the implementation of appropriate food safety practices.

Furthermore, teachers' perspectives were addressed in the reviewed studies. The importance of qualified teachers, in addition to quality curriculum, was demonstrated by Pivarnik et al. [17], in which some teachers preferred to have trained individuals in their classroom to execute the intervention programme. Reservations regarding the
If children can participate in experiments, they see their participation as an amusing game. 
Policy makers have to set minimum standards regarding who is qualified to teach food safety topics on all educational levels.

Given the considerable number of food-borne diseases occurring in domestic food preparation, it is obvious that we do not have GHKP, and we neglect the fact that the consumer is a crucial link in the food supply chain. pedagogical qualifications of invited chefs were also expressed by Craher et al. [35]. While Caraher [41] reported a lack of trained home economists in the UK, Ovca et al. [42] reported differences and deficiencies in Slovenian home economic teachers' formal education. Therefore, teacher education must not be neglected. One purpose of teacher education must be concerned with the issue of helping them to develop their understanding of the scientific concepts on which their teaching is based so that they feel skilled in teaching the concepts to children. Additionally, policy makers have to set minimum standards regarding who is qualified to teach food safety topics on all educational levels.

Most of the reviewed studies are short-term interventions in 40-90-minute workshops, up too few sessions in a certain period. Only two long-term programmes are described and evaluated in the reviewed literature $[39,40]$. Future school-based initiatives should take the time component into account as previous research has found an association between educational exposure and desired behaviour. Despite reports that food safety contents have been restricted in national curriculums or moved from compulsory to elective courses [43, 44], as a course, home economics represents the most suitable vehicle to systematically address challenges and to implement strategies in the education of primary school children related to microbiological food safety. Home economics education (among other courses) emphasizes critical thinking and holistic approaches [27]. From their qualitative findings, Brennan et al. [45] suggested that (besides gender and work status) formal home economics training plays a determining role in domestic food safety behaviour among adult consumers. Byrd-Bredbenner et al. [19] recommend a student-centred approach involving youth in the development and design of the education about food safety. With this approach, food safety education would have characteristics desired by youth. The importance of considering children's views and perceptions is also emphasised by Lange [46].

It has been shown that the present maintenance of food safety in the food supply chain can easily break down, because of different kind of barriers or simple misunderstandings [47, 48]. In the classic food supply chain strategy, all relevant activities are taken for the benefit of human beings, but the consumer is located outside the system. The consumer should be an integral part of food safety systems, because he/she is a vital link between retail and home. We expected that a wellinformed consumer would start to follow 'Good Housekeeping Practice' (GHKP), which is a selection of the principles and techniques of food storage and preparation at home performed directly by the consumer [47]. Given the considerable number of food-borne diseases occurring in domestic food preparation, it is obvious that we do not have GHKP, and we neglect the fact that the consumer is a crucial link in the food supply chain. Consumer behaviour and attitudes toward food safety show that the levels of understanding, motivation and trust need to be further cultivated. 


\section{CONCLUSIONS}

Teaching microbiological food safety and building awareness about food microbiology at the primary level is crucial, because behaviour is more easily influenced at that stage. Learning about food safety in schools makes it possible to influence children's behaviour with systemic measures; school-based education (on the primary level) in developed countries generally reaches all social classes. The development of proper teaching methodologies seems to be the key for the achievement of aware, confident and skilled students (on the consumer level) during primary education.

Raspor and Jevšnik [2] emphasised that it should be considered that safe food is the aim of all; therefore, every misleading act and information (intentional or unintentional) that could happen in the food supply chain, in the end, affect consumers. However, the status of food safety is the result of several factors, not only effective education, starting with a favourable domestic environment. All the players within food supply chains and all consumers have to experience proper education at the very early stage to imprint awareness about microorganisms and their role in food production, processing, distribution, preparation, and consumption. This is why we shall permanently improve and adapt teaching techniques to cope with the state of the art in fast changing societies around the globe.

\section{Acknowledgments}

The authors acknowledge the financial support from the Slovenian Research Agency (research core funding No. P3-0388). The authors would like to express their gratitude to Terry Jackson for language corrections.

\section{REFERENCES}

[1] Raspor P, Ambrožič M, Jevšnik M. Food chain safety management systems: the impact of good practices, In: Yanniotis $S$ (Ed.), Advances in food process engineering research and applications. New York, Springer. 2013: 607-625.

[2] Raspor P, JevšnikM. Food supply chains vs. food supply nets, In: Nedović VP, Raspor P, Lević J, Tumbas Šaponjac J, Barbosa-Cánovas GV (Eds.), Emerging and traditional technologies for safe, healthy and quality food, Elsevier. 2016: 9-32.

[3] Redmond EC, Griffith CJ. Consumer food handling in the home: A review of food safety studies. J Food Protect. 2003; 66(1): 130-161.

[4] Patil SR, Cates S, Morales R. Consumer food safety knowledge, practices, and demographic differences: findings from a meta-analysis. J Food Protect; 2005; 68: 1884-1894.

[5] Unusan N. Consumer food safety knowledge and practices in the home in Turkey. 2007. Food control; 18(1): 45-51.

[6] Wilcock A, Pun M, Khanonax J, Aung M.Consumer attitudes, knowledge and behaviour: a review of food safety issues. Trends food sci tech. 2004; 15: 56-66.

[7] Hillers VN, Medeiros L, Kendall P, Chen G, DiMascola S. Consumer food-handling behaviours associated with prevention of 13 foodborne illnesses. J Food Prot. 2003; 66(10):1893-1899.
Teaching microbiological food safety and building awareness about food microbiology at the primary level is crucial, because behaviour is more easily influenced at that stage.
All the players within food supply chains and all consumers have to experience proper education at the very early stage to imprint awareness about microorganisms and their role in food production, processing, distribution, preparation, and consumption. 
[8] Medeiros LC, Hillers VN, Chen G, Bergmann V, Kendall P, Schroeder M. Design and development of food safety knowledge and attitude scales for consumer food safety education. J Am Diet Assoc. 2004; 104: 1671-1677.

[9] Haapala I, Probart C. Food safety knowledge, perceptions, and behaviors among middle school students.J Nutr Educ Behav. 2004: 36: 71-76.

[10] Ovca A, Jevšnik M, Jereb G, Raspor P. Effect of educational intervention on young people, targeting microbiological hazards in domestic kitchens. Food Policy. 2016; 61: 156-162.

[11] Ovca A, Jevšnik M, Raspor P. Food safety awareness, knowledge and practices among students in Slovenia. Food Control. 2014; 42: 144151.

[12] Faccio E, Costa N, Losasso C, Cappa V, Mantovani C, Cibin V, Andrighetto I, Ricci A. What programs work to promote health for children? Exploring beliefs on microorganisms and on food safety control behavior in primary schools. Food Control. 2013; 33: 320-329.

[13] Mullan B, Wong C, Kothe EJ.Predicting adolescents' safe food handling using an extended theory of planned behavior. Food Control. 2013; 31, 454-460.

[14] Eves A, Bielby G, Egan B, Lumbers M, Raats M, Adams M. Food safety knowledge and behaviours of children (5-7 years). Health Educ J. 2010; 69: 21-30.

[15] Wills W, Backett-Milburn K, Gregory S, Lawton J. The influence of the secondary school setting on the food practices of young teenagers from disadvantaged backgrounds in Scotland. Health Educ Res. 2005; 20 : 458-465.

[16] Janacsek K, Fiser J, Nemeth D. The best time to acquire new skills: Age-related differences in implicit sequence learning across the human lifespan. Developmental Sci. 2012; 15: 496-505.

[17] Pivarnik LF, Patnoad MS GiddingsM. A food-safety curriculum for second- and third-grade elementary students. J Am Diet Assoc. 1994; 94: 865-868.

[18] Lavelle F, Spence M, Hollywood L, McGowan L, Surgenor D, McCloat A, Mooney E, Caraher M, Raats M, DeanM. Learning cooking skills at different ages: A cross-sectional study. Int J Behav Nutr Phy. 2016:13.

[19] Byrd-Bredbenner C, Abbot JM, Quick V. Food safety knowledge and beliefs of middle school children: Implications for food safety educators: Research in food science education. J Food Sci Edu. 2010; 9: 19-30.

[20] Lange M, Göranzon H, Fleig L, Marklinder I. Adolescents' sources for food safety knowledge and trust. Brit Food J. 2018; 120: 549-562.

[21] Caraher M, Baker H, Burns M. Children's views of cooking and food preparation. Brit Food J. 2004; 106: 255-273.

[22] John DR. Consumer socialization of children: A retrospective look at twenty-five years of research. J Consum Res. 1999; 26: 183-213.

[23] Christensen P, James A.Research with children: perspectives andpractices, London, Routledge. 2008.

[24] Eves A, Bielby G, Egan B, Lumbers M, Raats M, Adams M. Food hygiene knowledge and self-reported behaviours of UK school children (4-14 years). Brit Food J. . 2006; 108: 706-720.

[25] Abrahams I, Millar R. Does practical work really work? A study of the effectiveness of practical work as a teaching and learning method in school science. Int J Sci Edu. 2008; 30: 1945-1969.

[26] Moon A, Mulle M, Thompson R, SpellerV., Roderick P. Health-related research and evaluation in schools. Health Edu. 1999; 99: 27-34.

[27] Slater J. Is cooking dead? The state of Home Economics Food and Nutrition education in a Canadian province. Int J Consum Stud. 2013; 37: 617-624. 
[28] Bielby G, Egan B, Eves A, Lumbers M, Raats M, Adams M. Food hygiene education in UK primary schools: a nation-wide survey of teachers' views. Brit Food J. . 2006; 108: 721-731.

[29] Losasso C, Cappa V, Cibin V,Mantovani C,Costa N,Faccio E,Andrighetto I, Ricci A. Food Safety and Hygiene Lessons in the Primary School:Implications for Risk-Reduction Behaviors. Foodborne Pathog Dis. 2014; 11(1):68-74.

[30] Lange M, Palojoki P, Goranzon H, Marklinder I. Food safety teachinginfluenced by frames, traditions and subjective selections. Intl J Home Econ. 2017; 10(1):79-88.

[31] Lange M, Göranzon H, Marklinder I. 'Teaching Young Consumers' - food safety in home and consumer studies from a teacher's perspective. Int J Consum Stud. 2014; 38: 357-366.[32] Kim JM, Lee NH. Development of children food safety education program for 4th and 5th grade elementary school students in daegu and evaluation of its effects. J Korean Soc Food Sci Nutri. 2012; 41: 213-220.

[33] Zhou WJ, Xu XL, Li G, Sharma M, Qie YL, ZhaoY. Effectiveness of a school-based nutrition and food safety education program among primary and junior high school students in Chongqing, China. Global Health Prom. 2016; 23: 37-49.

[34] Traversa A, Adriano D, Bellio A, Bianchi DM, Gallina S, Ippolito C, Romano A, Durelli P, Pezzana A, Decastelli L. Food safety and sustainable nutrition workshops: Educational experiences for primary school children in Turin, Italy. Italian J Food Safety. 2017; 6: 9-12.

[35] Caraher M, Seeley A, Wu M, Lloyd S. When chefs adopt a school? An evaluation of a cooking intervention in English primary schools. Appetite. 2013; 62: 50-59.

[36] Marklinder I, Erikkson MK. Best-before date - Food storage temperatures recorded by Swedish students. Brit Food J. 2015; 117: 1764-1776.

[37] Faccio E, Costa N, Losasso C, Barrucci F, Mantovani C, Cibin V, Andrighetto I, Ricci A. Drawing instead of answering to evaluate the effectiveness of food safety programmes in primary school. Health EduJ. 2017; 76: 15-28.

[38] Lynch R., Steen MD, Pritchard TJ, Buzzell P., Pintauro SJ. Delivering food safety education to middle school students using a web-based, interactive, multimedia, computer program. J Food Sci Edu. 2008; 7: 35-42.

[39] Shen M, Hu M, Sun Z. Assessment of school-based quasi-experimental nutrition and food safety health education for primary school students in two poverty-stricken counties of West China. PLoS ONE. 2015; 10.

[40] Riyanto A, Murwani R, Sulistiyani Z, Rahfiludin M. Food safety education using book covers and videos to improve street food safety knowledge, attitude, and practice of elementary school students. Current Res Nutri Food Sci. 2017; 5: 116-125.

[41] Caraher M. Cooking in crisis. Lessons from the UK. Paper presented at the Dublin gastronomy symposium, 5th June, 2012. "<http://arrow.dit. ie/dgs/2012/ june512/6/>”, <http://arrow.dit.ie/dgs/2012/june512/6/> (accessed 24.09.12).

[42] Ovca A, Jevšnik M, Raspor P. Food safety education in primary school: the impact of home economics teacher. In: Almeida J, Paixão S (eds.). Global environmental health faculty forum. Environmental and Health International. 2015;16: 85-90.

[43] Byrd-Bredbenner C, Maurer J, Wheatley V, Schaffner D, Bruhn C, Blalock L. Food safety self-reported behaviors and cognitions of young adults: Results of a national study. J Food Protect. 2007; 70: 19171926.

[44] Griffith C, Redmond E. Evaluating hygiene behaviour in the domestic setting and the impact of hygiene education. J of Infection. 2001; 43: 70-74. 
[45] Brennan M, McCarthy M, Ritson C. Why do consumers deviate from best microbiological food safety advice? An examination of 'high-risk' consumers on the island of Ireland. Appetite. 2007; 49: 405-418.

[46] Lange M. Food Safety Learning in Home and Consumer Studies : Teachers' and Students' Perspectives, Digital Comprehensive Summaries of Uppsala Dissertations from the Faculty of Social Sciences. Acta Universitatis Upsaliensis, Uppsala, 2017. 81p.

[47] Raspor P, Jevšnik M. Good nutritional practice from producer to consumer. Crit Rev Food Sci. 2008; 48: 276-292.

[48] Raspor P. Total food chain safety: how good practices can contribute? Trend Food Sci Technol. 2008; 19(1): 405-412. 